\title{
Jurist-Diction
}

Volume 4 No. 6, November 2021

\section{Tanggung Gugat Akun Media Sosial Tanpa Identitas Asli Atas Perbuatan Melanggar Hukum}

\author{
Desy Ramadhani Pratini \\ desyrpratini@gmail.com \\ Universitas Airlangga
}

How to cite:

Desy Ramadhani Pratini,

'Tanggung Gugat Akun Media

Sosial Tanpa Identitas Asli Atas Perbuatan Melanggar Hukum' (2021) Vol. 4 No. 6 JuristDiction.

\section{Histori artikel:}

Submit 6 April 2021;

Diterima 15 Oktober 2021;

Diterbitkan 5 November 2021.

DOI:

10.20473/jd.v4i6.31846

p-ISSN: 2721-8392

e-ISSN: 2655-8297

\section{Abstract}

Liability (aansprakelejikeheidcausing) is a condition in which a party or a legal subject, if after committing an act of breaking the law, and losses to other parties must bear it. Unlawful acts can also be found on a social media platform, along with the types of accountability. There is a tendency for illegal acts committed by owners of social media accounts without identity because one of the social media platforms is not accompanied by verification of personal identity at the time of account creation. This unlawful act through social media accounts without real identity is an insult and defamation which is a special form of an illegal act. On the other hand, for the losses suffered by the victim, a civil suit against the law can be filed. However, due to difficulties in the civil lawsuit process, namely by not knowing the identity of the account owner. Then this can only be done if there is a final legally binding decision regarding criminal law.

Keywords: Unlawful; Liability of Liability; Social Media Accounts.

\begin{abstract}
Abstrak
Tanggung gugat (Liability/aansprakelejikeheid) merupakan suatu kondisi dimana pihak atau subjek hukum apabila setelah melakukan perbuatan melanggar hukum, dan membawa kerugian bagi pihak lain, ia harus menanggungnya. Perbuatan melanggar hukum dapat pula ditemui dalam suatu platform media sosial, disertai dengan jenis tanggung gugatnya. Kecenderungan terdapatnya perbuatan melanggar hukum yang dilakukan oleh pemilik akun media sosial tanpa identitas disebabkan oleh salah satu platform media sosial tidak disertai verifikasi identitas pribadi pada saat pembuatan akun. Perbuatan melanggar hukum melalui akun media sosial tanpa identitas asli ini adalah penghinaan dan pencemaran nama baik yang merupakan bentuk khusus dari perbuatan melanggar hukum. Di sisi lain, atas kerugian yang dialami oleh korban, dapat diajukannya upaya gugatan keperdataan dengan gugatan perbuatan melanggar hukum. Namun, dikarenakan terdapatnya kesulitan dalam proses gugatan keperdataan, yaitu dengan tidak diketahuinya identitas pemilik akun. Maka hal tersebut baru dapat dilakukan apabila terdapat putusan yang berkekuatan hukum tetap mengenai hukum pidana.

Kata Kunci: Perbuatan Melanggar Hukum; Tanggung Gugat; Akun Media Sosial.
\end{abstract}




\section{Pendahuluan}

Media sosial merupakan bentuk pengaktualan dari perkembangan teknologi informasi yang berbasiskan internet guna memudahkan penggunaanya dalam hal bekomunikasi, berpartisipasi, berbagi materi/konten, dsb. Dalam media sosial, agar para pengguna ini memiliki akun pribadi, harus terlebih dahulu mendaftarkan diri. Setelah itu, baru dapat mengunggah materi atau konten yang bersifat pribadi atau umum.

Terdapat beberapa media sosial yang paling banyak digunakan oleh masyarakat Indonesia pada sekarang ini, yaitu Facebook, Twitter, Instagram dan Tiktok. ${ }^{1}$ Namun jika diambil contoh pada platform Instragram, pada saat hendak mendaftarkan diri agar dapat memiliki akun, bertuliskan bahwa dengan mendaftarkan diri berarti pemilik akun telah menyetujui Terms, Data Policy dan Cookies Policy Instagram. Meskipun dalam Terms tersebut ketentuan yang dituliskan bahwa salah satu cara yang tidak diperbolehkan dalam menggunakan Instagram adalah pemilik akun tidak boleh menyamar sebagai orang lain atau memberikan informasi yang tidak akurat. Hal tersebut tidak didukung dengan adanya verifikasi data pribadi seperti halnya verifikasi dengan identitas pribadi, dsb. Dengan demikian, membuat para calon pemilik akun tidak ragu untuk membaut akun yang tidak disertai identitas aslinya atau anonim.

Tidak sedikit terdapat akun anonim yang diperuntukan untuk menyebarkan cerita orang lain dalap konteks yang negatif seperti halnya membuka aib, penghinaan, pencemaran nama baik dan semacamnya yang dapat merugikan suatu pihak tertentu. $^{2}$

Tentu saja dengan keberadaan akun anonim dapat merugikan pihak yang bersangkutan terutama untuk para selebritis. Kerugian yang ditimbulkan dapat berupa kerugian materiil ataupun kerugian immateriil, seperti rusaknya nama baik atau kehormatan pihak yang bersangkutan karena berita yang disajikan oleh akun

\footnotetext{
${ }^{1}$ Meita Fajriana, '4 Media Sosial yang Paling Banyak Digunakan Masyarakat Indonesia'(Fimela (Online), 2020) < https://www.fimela.com/lifestyle-relationship/read/4293104/4-media-sosial-yang-paling-banyak-digunakan-masyarakat-indonesia $>$ accessed 5 Agustus 2020.

${ }^{2}$ Nurul arifin, 'Fenomena Akun Pseudonym di Kalangan Pengguna Twitter Kota Makassar', Skripsi (Fakultas Ilmu Sosial dan Ilmu Politik, Makassar 2014).[7].
} 
anonim tersebut. Khususnya bagi selebriti nama baik juga merupakan salah satu aset yang bernilai karena akan mempengaruhi pendapatannya. Terlebih-lebih akun anonim ini sudah memiliki pengikut yang cukup banyak dan juga jejak digital sangat sulit atau hampir tidak bisa untuk dibersihkan.

Dalam ranah hukum perdata dikenal istilah tanggung gugat. Pihak yang telah merugikan ini memiliki tanggung gugat. Tanggung gugat (Liability/ aansprakelejikeheid) merupakan bentuk spesifik dari tanggung jawab. Tanggung gugat ini lebih ke arah dimana pihak atau subjek hukum apabila setelah melakukan perbuatan hukum yang mengakibatkan kerugian, ia harus menanggunggnya. Seperti halnya ada seseorang atau badan hukum telah melakukan perbuatan melanggar hukum yang mengakibatkan kerugian terhadap pihak lain, maka seseorang atau badan hukum ini harus membayar ganti kerugian terhadap pihak yang dirugikan tersebut. ${ }^{3}$ Seperti halnya akun anonim yang telah menimbulkan kerugian terhadap akun media sosial lainnya, pihak yang dirugikan oleh akun anonim ini dapat melakukan gugatan dengan landasan perbuatan melanggar hukum (onrechtmatige daad). Semula, istilah perbuatan melanggar hukum dimaknai secara sempit. Suatu perbuatan melanggar hukum baru dapat terpenuhi apabila seseorang melanggar ketentuan yang terdapat dalam undang-undang khususnya hak subjektif orang lain. ${ }^{4}$

\section{Unsur perbuatan melanggar hukum}

Berdasarkan pasal 1365 BW, dapat dikatakan melakukan suatu perbuatan melanggar hukum apabila telah memenuhi unsur-unsur sebagai berikut:

a. Terdapat suatu perbuatan;

Perbuatan yang dimaksud disini baik bertindak dalam melakukan suatu hal tertentu maupun tidak melakukan suatu hal tertentu. Dalam media sosial pemilik akun memiliki kuasa atas apa yang akan dilakukan terhadap akun miliknya. Seperti yang telah diketahui bahwasanya media sosial yang sebagai wadah

\footnotetext{
${ }^{3}$ Peter Mahmud Marzuki, Pengantar Ilmu Hukum, (Kencana 2008).[220].

${ }^{4}$ Yahman, Karakteristik Wanprestasi dan Tindak Pidana Penipuan: Yang Lahir dari Hubungan Kontraktual (Kencana 2014).[128].
} 
bertukar informasi, pendapat dan eksepresi pribadi. Dengan demikian, apabila kita menuangkan informasi, pendapat maupun ekspresi tersebut melalui akun media sosial sudah termasuk telah melakukan suatu perbuatan.

b. Perbuatan tersebut terbilang melanggar hukum;

Semenjak tahun 1919 perbuatan melanggar hukum ditafsir secara luas (termasuk hukum tidak tertulis), sebagai berikut: ${ }^{5}$

1. Perbuatan yang melanggar peraturan perundang-undangan;

Perbuatan yang dilakukan akun tersebut yaitu dengan menuangkan ekspresi pribadinya dalam bentuk kalimat negatif seperti menghinaan, dan mencemarkan nama baik yang ditujukan kepada pemilik akun lainnya. Hal ini sebagaimana mengacu pada ketentuan di Pasal 27 ayat (3) UU ITE bahwa: "Setiap orang dengan sengaja dan tanpa hak mendistribusikan dan/atau mentransmisikan dan/atau membuat dapat diaksesnya Informasi Elektronik dan/atau dokumen Elektronik yang memiliki muatan penghinaan dan/atau pencemaran nama baik." Dalam hal ini pemilik akun media sosial tersebut telah melanggar peraturan perundang-undangan.

2. Perbuatan yang melanggar hak subjektif orang lain;

Dengan telah menghina atau mencemarkan nama baik kepada pemilik akun lainnya telah melanggar hak kehormatan dan nama baik pemilik aku yang dihina

3. Perbuatan yang berlawanan dengan kewajiban si pelaku;

Salah satu kewajiban si pemilik akun dalam hal ini, yaitu pemilik akun Instagram adalah tidak boleh menyamar sebagai orang lain atau memberikan informasi yang tidak akurat, dan tidak boleh melakukan pelanggaran hukum yang menyesatkan, menipu maupun perbuatan untuk tujuan illegal atau dilarang. ${ }^{6}$ Dalam hal ini Instagram, tidak mengharuskan penggunanya untuk mengungkapkan identitas pribadinya. Namun, tidak seharusnya hal tersebut menjadi landasan untuk bebas melakukan hal yang seharusnya tidak boleh dilakukan seperti menghina dan mencemarkan nama baik orang lain. Setiap orang memiliki kewajiban untuk menghormati orang lain dan juga nama baiknya

4. Perbuatan yang bertentangan dengan kesusilaan (geode zeden);

Perbuatan menghina dan mencemarkan nama baik orang lain termasuk perbuatan melanggar kesusilaan.

5. Perbuatan yang bertentangan dengan kepatutan yang sesuai dalam masyarakat mengenai kepentingan orang lain.

Dalam hidup bermasyarakat sudah selayaknya untuk saling menghargai satu

${ }^{5}$ Leonora Bakarbessy dan Ghansham Anand, Buku Ajar Hukum Perikatan, (Zifatama Jawara, 2018). [238].

6 'Ketentuan Penggunaan'(Instagram (Online), 2020) <https://help.instagram. com $/ 581066165581870 /$ ?helpref $=$ hc_fnav\&bc[0] $=$ Bantuan $\% 20$ Instagram\&bc[1] $=$ Pusat $\% 20$ Privasi\%20dan\%20Keselamatan>, accessed 25 November 2020. 
sama lain, jika dalam hal tidak menyukai suatu hal tidak tidak seharusnya menuangkannya dalam bentuk penghinaan dan pencemaran nama baik. Apabila hal tersebut dilakukan telah terpenuhinya unsur terkahir ini. Tidak perlu menunggu semua unsur terpenuhi untuk dapat termasuk dalam perbuatan melanggar hukum. Salah satu unsur telah terpenuhi sudah dapat dikategorikan sebagai perbuatan melanggar hukum. Secara keseluruhan, unsur yang kedua telah terpenuhi.

c. Terdapat kerugian yang dialami oleh korban;

Dalam perbuatan melanggar hukum, kerugian yang diderita oleh korban dapat berupa kerugian kekayaan (vermogensschade) atau kerugian yang bersifat idiil. ${ }^{7}$ Dalam hal menghina dan mencemarkan nama baik yang dilakukan oleh pemilik akun tanpa identitas aslinya pun tentu membawa kerugian bagi korban. Perilaku tersebut membawa akibat kerugian immateriil seperti rasa malu, dan jatuhnya nama baik, yang berujung mengakibatkan kerugian materiil pula. Seperti halnya dengan jatuhnya nama baik berakibat pada sumber penghasilannya.

d. Terdapat kesalahan dari pihak pelaku;

Sebagaimana telah tertera dalam ketentuan Pasal 1365 BW, mensyaratkan kerugian yang dialami korban diakibatkan atas kesalahan yang diperbuat oleh pelaku. Di sisi lain, peraturan perundang-undangan mengharuskan perbuatan melanggar hukum yang dilakukan oleh pelaku harus mengandung unsur kesalahan (schuld). Dengan begitu, dapat dikatakan perbuatan melanggar hukum. ${ }^{8}$ Terdapat 2 (dua) macam pengertian kesalahan, pertama pengertian kesalahan dalam cakupan sempit, yaitu kesengajaan dimana apabila terdapat seseorang yang memilih untuk tetap melakukan suatu perbuatan sudah paham akan membawa akibat yang merugikan orang lain, hal tersebut dapat dipertanggungjawabkan. ${ }^{9}$ Kedua, kealpaan atau kurang berhati-hati. Hal ini sifatnya lebih ringan jika dibandingkan dengan kesengajaan. Perbuatan yang dilakukan oleh pemilik akun tanpa identitas asli ini termasuk dalam kesengajaan. Dimana, pemilik akun tersebut menyadari bahwa perbuatan tersebut tidak patut untuk dilakukan.

\footnotetext{
${ }^{7}$ Rosa Agustina, Perbuatan Melawan Hukum (Fakultas Hukum Universitas Indonesia,

${ }^{8}$ Leonora Bakarbessy dan Ghansham Anand, Op.Cit.[239].

${ }^{9}$ M.A. Moegni Djojodirdjo, Perbuatan Melawan Hukum (Pradnya Paramita 1982).[66].
} 2003). [75]. 
e. Terdapat hubungan kausalitas antara perbuatan pelaku dengan kerugian yang dialami korban.

Hubungan kausal antara perbuatan pelaku dengan kerugian yang dialami korban termasuk dalam salah satu syarat dari suatu perbuatan melanggar hukum. Dengan demikian, dalam ilmu hukum berfokus pada apakah kerugian yang dialami korban disebabkan oleh perbuatan yang dilakukan oleh pelaku. ${ }^{10}$

\section{Jenis Tanggung Gugat}

Istilah "tanggung gugat" ada untuk menerangkan adanya aansprakelijkheid. Artinya, menjunjung tinggi tanggung gugat atas apa yang telah dilakukan oleh seorang pelaku perbuatan melanggar hukum, maka si pelaku memiliki kewajiban untuk bertanggung jawab atas hal tersebut. Dimana, penderita atau korban akan mengajukan gugatan ke pengadilan yang ditujukan kepada pelaku, maka dari itu pelaku harus mempertanggung jawabkannya. ${ }^{11}$

a. Tanggung gugat berdasarkan kesalahan

Mengenai tanggung gugat ini, dalam beberapa bahasa dikenal istilah yaitu dalam bahasa Inggris dikenal dengan Liability base on fault, dan bahasa Belanda dikenal dengan Schuldaanspraklijkheid.Tanggung gugat berdasarkan kesalahan ini bentuk representasi dari ketentuan Pasal 1365 BW, bahwasanya tanggung gugat ada pada si pelaku yang telah menimbulkan kerugian pada orang lain, dan hal tersebut atas kesalahannya. Artinya, jika terdapat kerugian yang dirasakan oleh korban atau penderita, pelaku perbuatan melanggar hukum memiliki tanggung gugat hanya sebatas pada kesalahan yang diperbuat.

Dalam pasal 1365 BW melukiskan bahwa pembuktian dalam hal ini wajib dilakukan oleh penggugat selaku pihak yang dirugikan. Sebab, yang menjadi landasan hal tersebut adalah dalam istilah kesalahan (schuld) digunakan pula dalam

\footnotetext{
${ }^{10}$ Andrio Jackmico Kalensang, 'Hubungan Sebab Akibat (Causaliteit) dalam Hukum Pidana dan Penerapannya dalam Praktek', ejournal unsrat, Vol. V, No. 7, 2016, [12], < https://media.neliti. com/media/publications/146338-ID-none.pdf>.

${ }^{11}$ Munir Fuady, Perbuatan Melawan Hukum Pendekatan Kontemporer (Citra Aditya Bakti 2017).[113].
} 
makna kealpaan (onachtzaamheid) atau kurang berhati-hati, yang merupakan lawan dari kesengajaan. Kealapaan atau kurang hati-hati serta kesengajaan merupakan unsur kesalahan dalam arti luas. Sedangkan kesengajaan merupakan unsur kesalahan dalam arti sempit. Pembuktian ini selaras dengan ketentuan pasal 1865 BW yang menentukan yang bahwa "Setiap orang yang mendalilkan bahwa ia mempunyai sesuatu hak, atau guna meneguhkan haknya sendiri maupun membantah suatu hak orang lain, menunjkuk pada suatu peristiwa, diwajibkan membuktikan adanya hak atau persitiwa tersebut".

Secara normatifnya setiap perbuatan melanggar hukum di Indonesia selalu merujuk pada ketentuan Pasal 1365 BW. Maka dari itu, tanggung gugat berdasarka pasal $1365 \mathrm{BW}$ lebih bersifat umum. ${ }^{12}$

b. Tanggung gugat yang dipertajam

1. Tanggung Gugat Kesalahan Dengan Pembalikan Beban Pembuktian.

Tanggung gugat ini dalam bahasa Belanda disebut dengan Schuldaansprakeljikheid met omkering van de bewijslast. Pengaturan mengenai tanggung gugat ini diatur dalam ketentuan Pasal 1367 ayat (2) dan ayat (5) serta Pasal 1368 BW. Pasal 1367 ayat (2) BW menyebutkan bahwa: "Orang tua dan wali bertanggung jawab tentang kerugian, yang disebabkan oleh anak-anak belum dewasa, yang tinggal pada mereka dan terhadap siapa mereka melakukan kekuasaan orang tua atau wali”.

Unsur yang harus terpenuhi apabila para orang tua dan para wali dapat dipertanggung jawabkan atas perbuatan anak-anak belum dewasa, yaitu: a. orang tua dan wali harus bertempat tinggal bersama dengan anak-anak belum dewasa tersebut, b. Orang tua atau wali melakukan kekuasaan atau perwalian. Unsur tersebut bersifat kumulatif. Artinya, apabila terdapat anak yang belum dewasa melakukan suatu perbuatan melanggar hukum, tetapi tidak orang tua atau wali dari anak tersebut telah bercerai, atau tidak tinggal bersamanya, maka orang tua atau wali tersebut tidak dapat dipertanggung

\footnotetext{
${ }^{12}$ Leonora Bakarbessy dan Ghansham Anand, Op.Cit.[260].
} 
jawabkan sesuai ketentuan Pasal 1365 BW. ${ }^{13}$

Contoh: D memiliki anak berusia 3 tahun, anak si D merusak tanaman si G selaku tetangganya. Dalam hal ini D hanya bertanggung gugat atas kerugian yang diderita G. Jika dalam halnya D tidak melakukan kewajibannya selaku orang tua yang baik, dan menjaga atau mencegah anaknya agar tidak menimbulkan kerugian bagi orang lain. ${ }^{14}$ Itulah yang menjadi dasar hukum dari pertanggung jawaban yang harus dibebankan pada orang tua dan wali, yaitu kurangnya pengawasan (culpa in custodiendo) atas si anak, hal tersebut memiliki keeratan dengan ketenuan Pasal 1365 ayat (5) BW. ${ }^{15}$

Berdasarkan Pasal 1368 BW ayat (3) menyatakan yang intinya, jika terdapat kerugian yang dirasakan oleh pihak ketiga atas binatang tersebut, yang bertanggung jawab adalah pemilik seekor binatang tersebut, baik binatang tersebu ttelah dibawah pengawasannya, maupun terlepas dari pengawasannya. ${ }^{16}$

2. Tanggung gugat risiko

Tanggung gugat ini dalam bahasa belanda disebut dengan Risico aansprakeljikheid. Tanggung gugat ini telah diatur dalam ketentuan pasal 1367 ayat (3) BW. Secara garis besar tanggung gugat ini dimaksudkan sebagai majikan yang menanggung risiko atas apa yang perbuatan melanggar hukum yang dilakukan oleh pegawai yang bekerja untuk kepentingannya, dimana atas hal tersebut meninmbulkan kerugian bagi pihak ketiga.

c. Tanggung gugat luka dan kematian

Tanggung gugat luka diatur dalam ketentuan Pasal 1371 BW, yang pada intinya menjelaskan untuk setiap orang baik dengan sengaja maupun kurang kehati-hatian melakukan suatu perbuatan yang menyebabkan pihak ketiga terluka pada badannya, ia memiliki kewajiban untuk memberikan ganti kerugian. Dalam

\footnotetext{
${ }^{13}$ M.A. Moegni Djojodirdjo, Op.Cit.[121].

${ }^{14}$ Leonora Bakarbessy dan Ghansham Anand, Op.Cit.[261].

${ }^{15}$ M.A. Moegni Djojodirdjo, Loc.Cit.

${ }^{16}$ Leonora Bakarbessy dan Ghansham Anand, Op.Cit.[262].
} 
Pasal $1371 \mathrm{BW}$, tidak hanya kerugian terhadap harta kekayaan yang diperolehkan untuk menjadi dasar gugatan, melaikan juga pembayaran rasa sakit yang diderita akibat luka, serta kerugian immateriil seperti halnya kesedihan yang disebabkan luka. Dalam pasal ini menerangkan bahwa penderita atau korban mendapat ganti kerugian tidak berdasarkan kebutuhannya. Akan tetapi ganti kerugian yang didapatkan berdasarkan pada kemampuan dan kedudukan kedua belah pihak dan disesuaikan dengan keadaan. ${ }^{17}$

Dalam hal bentuk ganti kerugian, berdasarkan pasal 1370 BW ganti kerugian yang didapatkan hanya berkaitan dengan hilangnya penghasilan yang digunakan untuk hidup yang sebelumnya didapatkan dari penghasilan si korban. Akibatnya, pihak-pihak yang tidak dapat menuntut ganti kerugian immateriil adalah pihakpihak yang terdapat dalam Pasal 1370 BW. Dalam hal jumlah kerugian yang harus dibayarkan berdasarkan Pasal 1370 BW maksimalnya adalah berdasarkan jumlah kebutuhan dan kerugiannya diambil nilai terendah. Misalnya jumlah kebutahnnya Rp. 7.000.000,- sedangkan jumlah kerugiannya sebesar Rp. 9.000.000,- maka batas maksimum kewajiban membayar sebesar Rp. 7.000.000,--

Dalam hal kewajiban membayar hakim memiliki peran untuk menilai berdasarkan posisi dan harta kekayaan kedua belah pihak. Peringanan kewajiban membayar oleh pelaku dapat diberikan hakim apabila terdapat kemampuan pelaku untuk membayar tidak memadai, peringanan tersebut dapat berupa lebih rendahnya jumlah yang harus dibayarkan daripada jumlah minimum yang telah ditentukan. Selain itu, dapat pula kemungkinan hakim memberikan peringanan apabila dikarenakan dengan ketidak mampuan tergugat untuk membayar, kemudian tergugat mengangkut korban secara cuma-cuma.

d. Tanggung gugat karena penghinaan

Dalam BW penghinaan dan pencemaran nama baik diatur dalam ketentuan Pasal 1372-1380 BW. Dikarenakan penghinaan termasuk bentuk khusus dari perbuatan melanggar hukum. Penghinaan yang dimaksud dalam Pasal 1372-1380

${ }^{17}$ M.A. Moegni Djojodirdjo, Op.Cit.[164]. 
BW dimaksudkan termasuk dalam perbuatan yang sama sebagaimana telah tertera dalam bab XVI buku ke II KUHP dimana terdapat ancaman dengan hukuman. Dimana hal tersebut telah menjadi yurisprudensi tetap..$^{18}$

Suatu perbuatan dikatakan suatu penghinaan apabila dalam kedudukan masyarakat, dimana seseorang biasa yang memiliki perasaan jika telah disinggung nama baiknya sedemikian rupa. Sampai pantas pula jika nama baiknya mendapat pemulihan. Menurut bab XVI KUHP, perbuatan yang termasuk dalam penghinaan adalah menista, menista dengan surat, memfitnah, penghinaan biasa (eenvoudige belediging), fitnah dengan pengaduan (lasterlijke aan klacht). Berdasarkan perbuatan penghinaan, hal tersebut merupakan salah satu perbuatan dengan sengaja. Hal tersebut yang menjadi landasan Pasal 1372 BW yang mengharuskan dalam gugatan terdapat unsur kesengajaan. Dengan demikian, gugatan penghinaan tidak dapat dikabulkan apabila tidak terdapat maksud untuk menghina, dan hal tersebut ditegaskan oleh ketentuan Pasal 1376 BW. ${ }^{19}$

Dalam tuntutan keperdataan mengenai halnya penghinaan terdapat ketentuan khusus, dikarenakan penghinaan membawa akibat, yaitu dalam tuntutan tidak dapat didasarkan pada ketentuan Pasal 1365 BW, melainkan hanya didasarkan pada Pasal $1372 \mathrm{BW}^{20}$

Tuntutan berdasarkan pasal 1372 sampai dengan Pasal 1377 BW dapat dihapuskan atas dasar terdapat perdamaian dan pengampunan diantara para pihak antara lain pihak yang dihina dan pihak yang menghina. Berdasarkan ketentuan Pasal 1380 BW menjelaskan pada intinya dalam tenggang waktu satu tahun terhitung sejak penghinaan tersebut diketahui oleh orang yang dihina dapat dinyatakan tuntutan penghinaan tersebut gugur. ${ }^{21}$

\footnotetext{
${ }^{18}$ ibid, jo. Wirjono Prodjodikoro, Op.Cit.[97].

${ }^{19}$ Leonora Bakarbessy dan Ghansham Anand, Op.Cit.[278].

${ }^{20}$ M.A. Moegni Djojodirdjo, Op.Cit.[174].

${ }^{21}$ Leonora Bakarbessy dan Ghansham Anand, Op.Cit.[280].
} 


\section{Hubungan Para Pihak Dalam Media Sosial}

Seperti yang telah dijabarkan sebelumnya sasaran platform media sosial kali ini adalah Instagram. Para pihak dalam hal ini terdiri atas korban penghinaan dan pencemaran nama baik (pengguna Instagram juga), Pelaku (dalam hal ini pemilik akun media sosial tanpa identitas asli), penyelenggara Instagram.

Korban dalam hal ini mengetahui bahwasanya dirinya telah dihina dan nama baiknya telah dicemarkan, dan hal tersebut terjadi di tempat umum yaitu dalam hal ini platform media sosial Instagram dimana semua orang dapat mengaksesnya dan mengetahuinya. Sebagaimana telah dijabarkan sebelumnya, bahwa penghinaan dalam pasal 1373 BW dimaksudkan dalam penghinaan yang sama dalam KUHP serta mengharuskan adanya unsur kesengajaan dalam tuntutan.

Mengenai halnya tuntutan, yang menjadi dasar permohonan adalah landasan hukum dan peristiwa atau kejadian. Dengan demikian, hal tersebut sudah cukup memuat dan menjelaskan mengenai hubungan hukum (rechtsver houding) antara diri pemohon (dalam hal ini adalah korban penghinaan dan pencemaran nama baik) dengan permasalahan hukum yang dipersoalkan (penghinaan dan pencemaran nama baik). ${ }^{22}$

Jika dalam hal media sosial, seperti Instagram apabila telah terbentuknya akun Instagram tersebut dapat diartikan dan dianggap telah menyetujui perjanjian atau ketentuan yang telah dibuat oleh penyelenggara Instagram yang telah tertera dalam halaman yang sama pada saat hendak membuat akun Instagram. Seperti yang telah dijabarkan sebelumnya, salah satu ketentuan pengguna Instagram adalah berkomitmen untuk tidak melakukan perbuatan melanggar hukum. ${ }^{23}$ Dengan demikian, seharusnya calon pemilik akun tersebut membaca dan memahami ketentuan yang telah dibuat secara sepihak oleh penyelenggara Instagram. Namun, apabila tidak menyetujui ketentuan yang telah dibuat, maka calon pemilik aku tidak perlu tetap melanjutkan proses pembuatan akun tersebut.

\footnotetext{
${ }^{22}$ M. Yahya Harahap, Hukum Acara Perdata, Tentang Gugatan, Persidangam, Penyitaan, Pembuktian, dan Putusan Pengadilan (Sinar Grafika 2017).[34].

23 "Ketentuan Penggunaan" <https://help.instagram.com/1215086795543252?helpref=page content $>$ accessed 15 Desember 2020.
} 
Di sisi lain, terjadinya perbuatan melawan hukum dalam hal ini yaitu penghinaan dan pencemaran nama baik dalam suatu platform Instagram atau media sosial apapun itu, tentu saja tidak lahir dari suatu persetujuan antara pihak yang bersangkutan. Dengan demikian, walau tidak ada persetujuan sebelumnya tetapi terdapat kerugian yang dirasakan oleh salah satu pihak. Sehingga, terdapatlah hubungan hukum dalam hal ini, sebagaimana telah diatur dala ketentuan Pasal 1233 BW yang mengatakan bahwa perjanjian yang lahir karena undang-undang.

Dapat dikatakan dalam hal ini terdapat 2 (dua) hubungan hukum. Akan tetapi, dalam hal ini penyelenggara Instagram tidak berhubungan langsung dengan korban atau si penderita kerugiaan. Sebagaimana diatur dalam pasal 1340 BW yang merupakan implementasi dari asas privity of contract, yang artinya perjanjian yang dibuat oleh para pihak hanya mengikat dan menimbulkan akibat hukum bagi para pihak yang membuatnya.

Mengenai tanggung gugat dalam hal ini harus melihat dari hubungan hukumnya terlebih dahulu. Dalam penjabaran sebelumnya, pihak yang dirugikan atas akun media sosial tanpa identitas tidak dapat mengajukan gugatan kepada penyelenggara Instagram. Pihak yang bertanggung gugat dalam hal ini hanya akun tanpa identitas tersebut. Di sisi lain, di Indonesia mengenai tanggung jawab hukum untuk perantara internet dalam hal ini penyelenggara Instagram masih belum diatur atau masih terdapat kekosongan hukum pemerintah sendiri belum memiliki kebijakan konten internet yang illegal dan merugikan. ${ }^{24}$

\section{Upaya Gugatan Keperdataan oleh pihak yang dirugikan}

Jenis tanggung gugat yang dimiliki oleh pemilik akun dalam hal ini adalah tanggung gugat karena penghinaan. Dengan adanya tanggung gugat tersebut, pihak yang dirugikan dapat mengajukan gugatan keperdatan. Apabila dikaji dalam hukum keperdataan, memang pada dasarnya telah diatur terkait dengan penghinaan yang termasuk dalam kategori khusus dari perbuatan melanggar hukum, sebagaimana

${ }^{24}$ Adzkar Ahsinin, Policy Brief Tanggung Jawab Perantara dalam Tata Kelola Konten Internet (Seri Internet dan Hak Asasi Manusia Lembaga Studi dan Advokasi Masyarakat 2017).[2]. 
diatur dalam pasal 1372-1380 BW. Namun demikian, belum terdapatnya peraturan yang khusus terkait dengan adanya kerugian yang terjadi di ranah siber ini.

Dalam hukum acara perdata, tugas dan peran hakim bersifat pasif. Artinya, terdapat batasan dalam tugas dan peran hakim yaitu, sepanjang terkait dengan halhal yang diajukan oleh para pihak, hakim memiliki batasan untuk menerima dan memeriksanya. Sebatas kebenaran formil yang harus dicari dan ditemukan oleh hakim, dan perwujudan dari kebenaran formil tersebut berdasarkan atas alasan dan fakta yang diusung oleh para pihak selama proses persidangan berlangsung. ${ }^{25}$

Di sisi lain, terdapat permasalahan atau kesulitan yang dihadapi dalam proses gugatan, yaitu mengungkap siapa sosok dibalik akun media sosial tanpa identitas asli yang telah menimbulkan kerugian atas perbuatan melanggar hukum tersebut. Seperti yang telah dijabarkan sebelumnya, bahwa penghinaan pada media sosial ini diatur pula dalam Pasal 27 UU ITE yang selanjutnya mengenai sanksi pidananya diatur dalam Pasal 45 UU ITE. Maka dari itu, dengan berimplikasi pada hukum pidana, langkah hukum yang dapat ditempuh untuk mendapatkan identitas pelaku demi mendapatkan kebenaran materiil adalah dengan terlebih dahulu menempuh jalur pidana.

Setelah terdapat putusan yang berkekuatan hukum tetap terkait pidana yang dimaksud, dimana telah terdapat informasi mengenai siapa sosok dibalik akun media sosial tanpa disertai identitas aslinya. Dengan begitu, dengan putusan tersebut dapat dijadikan bukti dalam mengajukan upaya gugatan keperdataan perbuatan melanggar hukum. Apabila telah mendapatkan identitas yang dibutuhkan, hal tersebut dapat dicantumkan pada surat gugatan.

Lembaga peradilan umum atau pengadilan negeri memeriksa, mengadili dan memutus perkara pidana dan juga perkara perdata, sebagaimana telah diatur dalam ketentuan Pasal 25 ayat (2) Undang-Undang Nomor 48 Tahun 2009 Tentang Kekuasaan Kehakiman (selanjutnya disebut dengan "UU 48/2009”). Dalam ranah hukum perdata khusus mengadili perselisihan hubungan industrial, arbitrase,

${ }^{25}$ Munir Fuady, Op.Cit.[569]. 
konsumen, partai politik, niaga, dll. Di muka pengadilan negeri, mengenai halnya proses perdata dimulai dengan pengajuan surat gugatan yang diajukan oleh pihak yang bersangkutan atau kuasanya kepada ketua pengadilan negeri Terdapat 2 (dua) macam gugatan, yaitu yang pertama gugatan voluntair, dimana gugatan yang hanya diajukan oleh pemohon atau satu pihak saja, semata-mata demi terwujudnya kepentingan pemohon dan hanya diputus oleh pengadilan negeri yang biasanya dari permohonan lahirlah penetapan, lahir keputusan apabila permohonan pengangkatan anak oleh warga Negara asing terhadap warga Negara Indonesia ataupun sebaliknya (sebagaimana telah diatur dalam Surat Edaran Mahkamah Agung No. 2 Tahun 1979). Kedua, gugatan contentiosa ${ }^{26}$ yang diajukan kepada pengadilan dengan posisi para pihak: ${ }^{27}$

a. Sebagai penggugat, untuk pihak yang mengajukan gugatan atau pihak yang merasa hak keperdataannya dilanggar.

b. Sebagai tergugat, untuk pihak lawan dalam gugatan tersebut.

c. Mengandung sengketa dalam permasalahan hukum yang diajukan ke pengadilan.

d. Paling sedikit terjadi sengketa di antara 2 (dua) pihak.

e. Bersifat partai, yang artinya terdapat komposisi yaitu pihak penggugat dan pihak tergugat.

Dalam gugatan contentiosa ini terbagi menjadi 5 (lima) yaitu: ${ }^{28}$

a. Gugatan biasa

Mengenai prosedurnya untuk gugatan ini sebagaimana diatur dalam Herzien Inlandsch Reglement (selanjutnya disebut "HIR").

b. Gugatan sederhana

Perkara yang dapat diajukan dalam gugatan sederhana apabila perkara yang nilai materiilnya tidak lebih dari Rp. 200.000.000 (dua ratus juta rupiah), bukan perkara tanah, bukan perkara yang diatur oleh peradilan khusus (seperti peradilan niaga, hubungan industrial, dll), dan para pihak (penggugat dan tergugat) berada dalam daerah hukum pengadilan yang sama. Penjelasan lebih lanjut

\footnotetext{
${ }^{26}$ Mohammad Saleh, Gugatan Perdata yang diajukan ke Pengadilan Negeri atau Peradilan Umum, Kuliah Umum dalam Hukum Acara Perdata pada Fakultas Hukum Universitas Airlangga, Surabaya, 23 Agustus 2018.

${ }^{27}$ M. Yahya Harahap, Op.Cit.[49-50].

${ }^{28}$ Mohammad Saleh, Loc.Cit.
} 
diatur dalam Peraturan Mahkamah Agung (selanjutnya disebut "PERMA") No. 2 Tahun 2015 tentang Tata Cara Penyelesaian Gugatan Sederhana.

c. Gugatan Perwakilan Kelompok (class action).

Gugatan yang diajukan oleh salah satu orang atau beberapa yang bertindak sebagai perwakilan kelompok atas nama kelompok yang mereka wakili, tanpa surat kuasa dari anggota kelompok. Gugatan ini diajukan dikarenakan memiliki persamaan kepentingan, dan persamaan penderitaan. Gugatan ini diatur dalam ketentuan PERMA No. 1 Tahun 2002. ${ }^{29}$

d. Gugatan untuk kepentingan umum.

Gugatan yang diajukan oleh Lembaga Swadia Masyarakat yang sudah berstatus badan hukum

e. Keberatan atas putusan.

Keberatan atas putusan ini dapat diajukan jika ada pihak yang merasa keberatan atas keputusan Komisi Pengawas Persaingan Usaha (KPPU) yang diatur dalam PERMA No. 3 Tahun 2005, keberatan atas Keputusan Badan Penyelesaian Sengketa Konsumen (BPSK) dimana konsumen dapat mengajukan keberatan ke BPSK atau Pengadilan Negeri tetapi tidak semua putusan BPSK dapat dibawa ke Pengadilan Negeri hanya putusan yang bersifat arbitrase(perdamaian) yang dapat diajukan, keberatan atas putusan arbitrase yang diatur dalam PERMA No. 1 Tahun 2006, keberatan atas perkara partai politik.

Selain jenis-jenis gugatan, terdapat pula bentu-bentuk gugatan, pertama gugatan lisan. Dasar terbentuknya gugatan lisan adalah demi menunjang banyak kepentingan masyarakat buta huruf yang pada saat itu HIR dibuat tahun 1941, dan juga meringankan beban rakyat kecil yang pada saat itu belum mampu menunjuk seorang kuasa untuk mewakilinya.Ketentuan mengenai gugatan lisan diatur dalam pasal 120 HIR. Kedua, gugatan tertulis yang merupakan gugatan yang paling diutamakan. Bentuk gugatan ini diatur dalam pasal 118 ayat (1) HIR. Gugatan perdata beserta dengan surat permintaan yang ditandatangi oleh penggugat ataupun

${ }^{29}$ M. Yahya Harahap, Op.Cit. [187]. 
kuasanya harus diterima oleh pengadilan negeri. Pihak yang berhak membuat gugatan adalah penggugat ataupun kuasanya. Namun, apabila gugatan tersebut dibuat oleh kuasanya harus terlebih dahulu mendapat kuasa yang dibuktikan dengan surat kuasa dari penggugat.

Dalam kasus ini jenis gugatan yang cocok untuk diajukan adalah gugatan biasa atau juga dapat mengajukan gugatan sederhana, apabila kerugian yang diderita pihak penggugat tidak melebihi dari Rp. 200.000.000 (dua ratus juta rupiah) atau setelah mengetahui keberadaan pihak tergugat,dan ternyata penggugat dan tergugat berdomisili pada daerah hukum pengadilan yang sama.

Terdapat pula formulasi surat gugat yang dimaksudkan sebagai perumusan pemenuhan syarat formil, yaitu: ${ }^{30}$

1. Ditujukan kepada pengadilan negeri.

hal tersebut ditujukan sesuai dengan kompetensi relatif (yang akan dijelaskan lebih lanjut pada sub bab berikutnya).

2. Diberi tanggal.

Hal ini dilakukan demi menjamin kepastian hukum terhadap surat gugatan tersebut, sampai jika pada akhirnya timbul permasalahan mengenai tanggal pembuatan surat gugatan dan tanggal beserta penandatanganan surat kuasa dapat segera diselesaikan.

3. Ditandatangani penggugat atau kuasanya.

Pada pasal 118 ayat(1)HIR telah mengatur mengenai tanda tangan. Tanda tangan dapat ditulis dengan tangan sendiri yang dapat dilakukan oleh penggugat sendiri atau kuasanya dengan catatan apabila ditandatangi oleh kuasanya harus terlebih dahulu dibuat dan diserahkannya surat kuasa khsuus. Selain itu berdasarkan St. 1919-776 terdapat cap jempol yang disamakan dengan tanda tangan. Jadi, apabila penggugat tidak dapat menandatanginya dapat dilakukan cap jempol pada surat gugatan tesebut. Dengan catatan agar cap jempol tersebut benarbenar sah sebagai pengganti tanda tangan, harus terlebih dahulu dilegalisir oleh

\footnotetext{
${ }^{30}$ ibid. [53-69].
} 
pejabat yang bewenang seperti camat, panitera atau hakim. Seperti yang telah diketahui sebelumnya, bahwa dalam hal ini penggugat merupakan pihak yang telah dirugikan akibat penghinaan dan pencemaran nama baik oleh akun media sosial tanpa identitas aslinya (tergugat).

4. Identitas para pihak.

Gugatan dapat dinyatakan tidak sah dan dianggap tidak ada apabila didalamnya tidak memuat identitas para pihak terutama identitas tergugat. Identitas yang wajib termuat, yaitu pertama nama lengkap termasuk gelar atau alias jika memang hal tersebut ada, hal tersebut dilakukan demi menghindari kesalahan pencantuman identitas yang diakibatkan persamaan nama pada lingkungan temapat tinggal. ${ }^{31}$ Kedua, alamat atau tempat tinggal tergugat yang meliputi alamat kediaman utama, kediaman tambahan lainnya, atau tempat tinggal riil. Informasi mengenai alamat tersebut dianggap sah apabila didapatkan melalui kartu atau surat identitas tergugat seperti Kartu Tanda Penduduk (KTP), Kartu Keluarga (KK), atau Nomor Pokok Wajib Pajak (NPWP). Di lain sisi, jika terdapat surat gugatan yang telah diajukan dan ternyata terdapat perubahan dalam alamat tergugat hal tersebut tidak membuat surat gugatan cacat formil. Keempat, penyebutan identitas lain sebagai pelengkap seperti halnya agama, dan suku bangsa.

\section{Fundamentum petendi}

Hal ini disebut juga posita atau dasar gugatan. Unsur dari dasar gugatan harus memenuhi dua unsur agar dapat dianggap lengkap, yaitu dasar hukum dan dasar fakta atau peristiwa yang menjadi dasar gugatan, lebih-lebih mengenai hal yang relevan menurut hukum. Dalam kasus ini, dasar hukum yang menjadi dasar gugatan adalah Pasal 1372 - 1380 BW. Sedangkan untuk dasar fakta yang menjadi dasar gugatan adalah pencemaran nama baik dan penghinaan yang yang telah dilakukan oleh tergugat dengan sengaja, yang pada akhirnya mengakibatkan kerugian materiil dan immateriil seperti tercemarnya nama baik

${ }^{31}$ ibid.[56]. dikutip dari Abdulkadir Muhammad, Hukum Acara Perdata Indonesia (Citra Aditya Bakti 1992).[41]. 
dan kehormatan penggugat.

6. Petitum gugatan.

Agar gugatan tidak mengandung cacat formil dan dianggap sah, petitum gugatan harus pula dicantumkan dalam gugatan. Petitum gugatan berisikan tuntutan penggugat kepada pengadilan negeri untuk menghasilkan keputusan dimana hak penggugat telah dilanggar dan mendapat ganti kerugian. Dalam kasus ini, tuntutan keperdataan mengenai halnya penghinaan berdasarkan Pasal 1372 dan Pasal 1373 BW dapat mencakup ganti kerugian berupa penggantian uang serta kerugian immateriil (Pasal 1373 BW), pemulihan kehormatan dan nama baik serta keputusan berdasarkan pasal 1372 BW dinyatakan perbuatan penghinaan atau fitnah, dan dengan biaya yang ditanggung oleh pelaku keputusan tersebut ditempelkan di tempat umum. ${ }^{32}$ Hal yang harus diperhatikan dalam menyusun baik posita maupun petitum adalah hubungan hukum para pihak dan kolerasi antara postia dan petitum itu sendiri.

7. Perumusan gugatan accesoir

Gugatan accesoir adalah gugatan tambahan dari gugatan pokok. Melingkupi segala hal yang dibenarkan dalam undang-undang, dan demi menjamin kepentingan penggugat, penggugat dapat mencantumkan gugatan accesoir untuk melengkapi gugatan pokoknya. Akan tetapi, untuk mengajukan gugatan accesoir terdapat syarat yang harus terpenuhi. Secara teori dan praktik dikarenakan gugatan accesoir tidak dapat berdiri, keberadaannya hanya dapat diperbolehkan jika ditempatan dalam bagian akhir gugatan pokok. Selain itu, syarat yang gugatan accesoir lainnya adalah tidak bertentangannya gugatan pokok dengan gugatan accesoir, diantara keduanya harus saling mendukung. Meskipun terdapat kaitannya dengan kepentingan penggugat, gugatan accesoir sangat erat hubungannya dengan gugatan pokok. Di sisi lain, demi melindungi kepentingan penggugat juga terdapat jenis-jenis gugatan accesoir yang dianggap paling penting yaitu pertama, gugatan provisi yang sesuai dengan

\footnotetext{
${ }^{32}$ M.A. Moegni Djojodirdjo, Op.Cit.[169].
} 
ketentuan Pasal 180 ayat(1)HIR. Dalam gugatan ini berisikan bahwa penggugat dapat menuliskan permintaan yang berkaitan dengan tindakan sementara agar ditaati oleh tergugat sebelum perkara pokok memperoleh kekuatan hukum tetap, sebagaimana diputus oleh pengadilan negeri yang menjatuhkan putusan provisi sebelum perkara pokok diperiksa. Kedua, gugatan tambahan mengenai penyitaan yang sesuai dengan ketentuan Pasal 226 dan Pasal 227 HIR. Penyitaan dilakukan untuk menjaga kemungkinan hilang atau diasingkannya barangbarang tersebut oleh terugat selama proses perkara berlangsung, penyitaan ini dilakukan oleh pengadilan dengan menempatkan harta kekayaan atau barang objek sengketa tergugat ke dalam keadaan penyitaan. Ketiga, gugatan tambahan permintaan nafkah yang sesuai dengan ketentuan Pasal 24 ayat (2) Huruf a PP No. 9 Tahun 1975. Dalam kasus ini, jenis gugatan accesoir yang dapat digunakan adalah gugatan provisi seperti halnya menghentikan tergugat untuk meneruskan perhinaan atau pencemaraan nama baik di media sosialnya, yang dapat menggiring akun media sosial lainnya.

\section{Kesimpulan}

Dalam pasal 1372-1380 BW mengatur khusus mengenai perbuatan melanggar hukum termasuk penghinaan, dimana hal tersebut termasuk fitnah. Perbuatan melanggar hukum melalui akun media sosial yang dilakukan oleh pemilik akun tanpa identitas aslinya adalah penghinaan dan pencemaran nama baik. Perbuatan penghinaan termasuk bentuk khusus dari perbuatan melanggar hukum. Dalam hal ini, pemilik akun tersebut memiliki tanggung gugat. Jenis tanggung gugat yang dimiliki adalah tanggung gugat karena penghinaan. Upaya gugatan keperdataan yang dapat diajukan oleh pihak yang dirugikan akibat akun media sosial tanpa disertai identitas aslinya atas perbuatan melanggar hukum adalah mengajukan gugatan perbuatan melanggar hukum yang didasarkan pada pasal 1372-1380 BW disertai dengan petitum gugatan yang berisikan ganti kerugian. Namun, hal tersebut baru dapat dilakukan apabila terdapat putusan yang berkekuatan hukum tetap mengenai hukum pidana. Artinya, sebelum menempuh jalur perdata, pihak yang dirugikan dapat menempuh jalur 
pidana terlebih dahulu demi terwujudnya kebenaran materiil. Hal tersebut dilakukan karena terdapatnya kesulitan dalam proses gugatan keperdataan, yaitu dengan tidak diketahuinya identitas pemilik akun.

\section{Daftar Bacaan}

\section{Buku}

Adzkar Ahsinin, Policy Brief Tanggung Jawab Perantara dalam Tata Kelola Konten Internet (Seri Internet dan Hak Asasi Manusia Lembaga Studi dan Advokasi Masyarakat 2017).

Leonora Bakarbessy dan Ghansham Anand, Buku Ajar Hukum Perikatan, (Zifatama Jawara 2018).

M. Yahya Harahap, Hukum Acara Perdata, Tentang Gugatan, Persidangam, Penyitaan, Pembuktian, dan Putusan Pengadilan (Sinar Grafika 2017).

M.A. Moegni Djojodirdjo, Perbuatan Melawan Hukum (Pradnya Paramita 1982).

Munir Fuady, Perbuatan Melawan Hukum Pendekatan Kontemporer (Citra Aditya Bakti 2017).

Peter Mahmud Marzuki, Pengantar Ilmu Hukum (Kencana 2008).

Rosa Agustina, Perbuatan Melawan Hukum (Fakultas Hukum Universitas Indonesia 2003).

Yahman, Karakteristik Wanprestasi dan Tindak Pidana Penipuan: Yang Lahir dari Hubungan Kontraktual (Kencana 2014).

\section{Jurnal}

Andrio Jackmico Kalensang, 'Hubungan Sebab Akibat (Causaliteit) dalam Hukum Pidana dan Penerapannya dalam Praktek' (2016)Vol. V No 7 ejournal unsrat. [12], < https://media.neliti.com/media/publications/146338-ID-none.pdf $>$.

\section{Kuliah Umum}

Mohammad Saleh, Gugatan Perdata yang diajukan ke Pengadilan Negeri atau Peradilan Umum, Kuliah Umum dalam Hukum Acara Perdata pada Fakultas Hukum Universitas Airlangga, Surabaya, 23 Agustus 2018. 


\section{Laman}

'Ketentuan Penggunaan'(Instagram (Online), 2020) <https://help.instagram. $\mathrm{com} / 581066165581870 /$ ?helpref=hc_fnav\&bc[0]=Bantuan\%20 Instagram \&bc[1] $=$ Pusat $\% 20$ Privasi $\% 20$ dan $\% 20$ Keselamatan $>$, accessed 25 November 2020.

“Ketentuan Penggunaan” (Instragram Online), 2020) $<$ https://help.instagram. com/1215086795543252?helpref=page_content $>$, accessed 15 Desember 2020 .

Meita Fajriana, '4 Media Sosial yang Paling Banyak Digunakan Masyarakat Indonesia'(Fimela (Online), 2020) <https://www.fimela.com/lifestylerelationship/read/4293104/4-media-sosial-yang-paling-banyak-digunakanmasyarakat-indonesia $>$ accessed 5 Agustus 2020.

\section{Skripsi}

Nurul arifin, 'Fenomena Akun Pseudonym di Kalangan Pengguna Twitter Kota Makassar', Skripsi, (Fakultas Ilmu Sosial dan Ilmu Politik, Makassar, 2014). 
Desy Ramadhani: Tanggung Gugat Akun...

--halaman ini sengaja dibiarkan kosong-- 